\title{
Low plasma haptoglobin in march haemoglobinuria
}

\author{
R. B. PAYNE
}

From the Department of Chemical Pathology, University of Leeds

SYNOPSIS A student had haemoglobin in the urine after running but not after cycling. The haemoe globinuria was related to the hardness of the surface on which he ran and to his running style. The concentration of haptoglobin in his plasma was less than normal. This was most pronounced aft he had been running, when haptoglobin had combined with free haemoglobin, but the concentration was also low when there had been no haemolysis for six weeks. Thus two factors combined to gives him haemoglobinuria: lysis of red cells by mechanical damage and lack of haptoglobin to combinet with liberated haemoglobin.

Haemoglobinuria after marching or running is rare, although haemoglobinaemia is more common (Gilligan, Altschule, and Katersky, 1943). Haemoglobin will pass from the plasma into the urine only when the haemoglobin-binding capacity of the plasma haptoglobin has been saturated (Laurell and Nyman, 1957; Allison and Rees, 1957), suggesting that usually the amount of haptoglobin in the plasma is sufficient to combine with all the haemoglobin released during exercise. Davidson (1964) and Buckle (1965) found low plasma haptoglobin concentrations in patients with march haemoglobinuria even before exercise. They believed that haptoglobin had been removed by repeated episodes of haemolysis. When exercise is being taken frequently it is difficult to decide whether haptoglobin is low because of repeated haemolysis, or whether a persistently low haptoglobin concentration had predisposed to haemoglobinuria. This is the report of a student with haemoglobinuria after cross-country running who had a persistently low plasma haptoglobin concentration unrelated to haemolysis.

\section{CASE REPORT}

R.S. was 18 when seen in October 1962. He was a member of the University cross-country team. His only complaint was that he passed dark red. urine for some hours after cross-country runs. He first noticed this in March 1961 when he had started running.

He had exerted himself as hard and as long before 1961 when cycle racing, but had never had red urine afterwards.

He had had no serious illnesses. He was a fit youth with good muscular development and physical examination was normal. He was not jaundiced and the spleen was not enlarged. There was no history of a similar condition in

Received for publication 14 September 1965. his family. His maternal grandfather had been a cross̆ country runner for 25 years, but had never noticed ree urine.

INVESTIGATIONS His urine was examined several times immediately after he had been running. It was clear ang dark red and contained protein. The centrifuged depost contained a few granular casts, but no red cells. Red cels added to the urine were not lysed. The characteristio absorption bands of haemoglobin were seen with th spectroscope and the elution volume of the pigment from a Sephadex G200 column was the same as that of haemos globin. There was no excess of urobilinogen. Bilirubin porphyrins, and porphobilinogen were not detected. Theng was no cystine, although cystinuria is said to be common in march haemoglobinuria (Pare and Sandler, 1954).

Table I shows some measurements made on his bloog before and after a five-mile race which was largely on roads. Plasma haemoglobin was determined by the method of Hunter, Grove-Rasmussen, and Soutter (1950) Haptoglobin was measured as haemoglobin-binding capacity by an electrophoretic method (Bodman, 1960 The normal haptoglobin concentration by this method over $40 \mathrm{mg}$. per $100 \mathrm{ml}$.

The proportion of reticulocytes was usually less tha $1 \%$, but once, the day after a race, it was $3 \%$. The tota

TABLE I

PATIENT'S PLASMA HAEMOGLOBIN AND HAPTOGLOBIN BEFORE AND AFTER A 5-MILE RACE Haemoglobin (mg.per $100 \mathrm{ml}$.) $\quad \begin{aligned} & \text { Haptoglobin } \\ & \text { (mg.per } 100 \mathrm{ml} .)\end{aligned}$

Before running

o

20

Hours after running

$\begin{array}{rr}0 & 150 \\ 1 & 53 \\ 2 & 20 \\ 4 & 0\end{array}$

$\mathbf{0}$

$\mathbf{0}$

0 
serum bilirubin, measured several times, was $1.0 \mathrm{mg}$. per $100 \mathrm{ml}$.

The blood haemoglobin was never below $14.8 \mathrm{~g}$. per $100 \mathrm{ml}$. Electrophoresis showed that it was $\mathrm{Hb} \mathrm{A}$. The cells were morphologically normal. An anti-globulin test and an acidified serum test were negative, and the osmotic and mechanical fragility of the cells and autohaemolysis were normal (Dacie and Lewis, 1963). Oxygen uptake and glucose utilization in the presence and absence of methylene blue were normal (Brin and Yonemoto, 1958).

The haptoglobin type was 1-2 (Smithies, 1955). When the patient was running weekly or twice a week the haptoglobin level ranged from 0 to $20 \mathrm{mg}$. per $100 \mathrm{ml}$. The haptoglobin level measured after five weeks' rest was $30 \mathrm{mg}$. per $100 \mathrm{ml}$., and it was the same a week later. In normal persons haptoglobin depleted by transient intravascular haemolysis or the injection of haemoglobin returns to a normal level within about seven days (Laurell and Nyman, 1957).

The persistently low haptoglobin level could have been due to continuing intravascular haemolysis, even though there was no clinical or laboratory evidence of a chronic haemolytic process, so the survival of the patient's own red cells labelled with ${ }^{51} \mathrm{Cr}$ was studied. The mean cell survival was found to be within normal limits.

PROGRESS The patient was told that mechanical damage to red cells in the soles of the feet was the probable cause of the haemolysis and haemoglobinuria (see Discussion). He ran with Sorbo rubber insoles in his running shoes and found that this prevented haemoglobinuria. He has altered his running style, which was rather high-stepping and flat-footed with a lumbar lordosis. He now runs on the balls of the feet. Since adopting this new running style he has had slight haemoglobinuria only rarely.

FAMILY STUDIES The patient's family (his sister, both parents, and his maternal grandfather) were examined. None had anaemia and there was no clinical or laboratory evidence of excessive haemolysis. The sister, mother, and maternal grandfather had haptoglobin levels of $50 \mathrm{mg}$. per $100 \mathrm{ml}$, and the father $80 \mathrm{mg}$. per $100 \mathrm{ml}$.

TEAM STUDIES The patient and four volunteers from the University cross-country team had blood and urine samples taken before and after a five-mile run, mainly on roads. Only the patient had haemoglobinuria. His serum haemoglobin was $122 \mathrm{mg}$. per $100 \mathrm{ml}$. after the run. Of the other four runners, three had significant haemoglobinaemia after running, with plasma haemoglobin concentrations of 13, 48, and $103 \mathrm{mg}$. per $100 \mathrm{ml}$. The pre-exercise haptoglobin concentrations in these three students were sufficient to combine with all the haemoglobin released, so there was no haemoglobinuria. They had all run as often as the patient and so had had an equal opportunity to deplete the plasma haptoglobin.

\section{DISCUSSION}

A great deal of laboratory work has been done to find a haemolytic mechanism in march haemoglobinuria, but without success. No red cell abnormality has been detected. When haemoglobinuria follows exercise in the upright posture it has often been noted, as in the student described here, that it is not produced by equally strenuous exercise in other postures, for example by cycling. The extensive literature has been reviewed by Martin and Kilian (1959) and Davidson (1964).

The first clue to the cause of the haemolysis came from Attlee (1937). He described two school boys who had no symptoms even after strenuous running on grass, but always had haemoglobinuria after running on roads. Davidson (1964) clearly established that the haemolysis is related to mechanical damage to red cells in the soles of the feet, a combination of the hardness of the running surface and of the running style, and this has been confirmed by Buckle (1965). Crosby (1965) pointed out that the suggestion that haemolysis could be caused by superficial trauma had been made earlier by Ensor and Barratt (1903). These authors described a patient with 'paroxysmal haemoglobinuria of traumatic origin'. He was a schizophrenic who used to slap his forehead and thigh violently for an hour or more. Whenever he did this he had haemoglobinuria afterwards. Ensor and Barratt suggested that haemolysis followed damage to the red cells in the skin.

Haemoglobinuria is more likely to follow haemoglobinaemia when the plasma haemoglobin-binding capacity is low. Repeated episodes of haemolysis will cause a transient depletion of haptoglobin. Kast (1884) noted that the less his patient rested between periods of exertion, the shorter the walking distance necessary to produce haemoglobinuria. Low haptoglobin levels before exercise have therefore been attributed to repeated exercise causing repeated haemolysis (Davidson, 1964; Buckle, 1965). Even when there was no haemolysis our student had persistently low plasma haptoglobin concentrations. His family had normal concentrations. Familial hypohaptoglobinaemia has been described only in the haptoglobin phenotypes 1-2 and 2-2 and not in the phenotype 1-1, suggesting that a modification of the $\mathrm{Hp} 2$ allele is responsible for the low concentration (Gottlieb, Wisch, and Ross, 1963). It is likely that families with this condition may be traced through persons with march haemoglobinuria.

Nagel and Ranney (1964) reported that haemoglobin $\mathrm{H}$, which is a tetramer of the $\beta^{A}$ polypeptide chain, and haemoglobin Barts, which is a tetramer of the $\gamma^{F}$ chain, are not bound by normal haptoglobins, whereas all haemoglobins containing two $\alpha^{A}$ chains are. Persons with haemoglobin $\mathbf{H}$ or Barts presumably cannot bind their own haemoglobin, so it is possible that these haemoglobins will be found more commonly in subjects with march haemoglobinuria than in the general population. 
TABLE II

FACTORS CONTRIBUTING TO MARCH HAEMOGLOBINURIA

\begin{tabular}{|c|c|c|}
\hline Author & $\begin{array}{l}\text { Mechanical Factors } \\
\text { Causing Increased } \\
\text { Haemolysis }\end{array}$ & $\begin{array}{l}\text { Factors Reducing } \\
\text { Capacity to Bind } \\
\text { Haemoglobin }\end{array}$ \\
\hline $\begin{array}{l}\text { Kast (1884) } \\
\text { Attlee (1937) }\end{array}$ & Hard road or track & $\begin{array}{l}\text { Frequently repeated } \\
\text { exercise }\end{array}$ \\
\hline $\begin{array}{l}\text { Davidson } \\
\text { (1964) }\end{array}$ & $\begin{array}{l}\text { Flat-footed style of } \\
\text { walking or running }\end{array}$ & $\begin{array}{l}\text { Primary deficiency of } \\
\text { plasma haptoglobin (the } \\
\text { present patient). }\end{array}$ \\
\hline $\begin{array}{l}\text { Gilligan et al. } \\
\text { (1943) }\end{array}$ & $\begin{array}{l}\text { Increased susceptibility } \\
\text { of red cells to trauma }\end{array}$ & $\begin{array}{l}\text { Failure of haptoglobin to } \\
\text { bind haemoglobin (HbH } \\
\text { or Hb Barts). } \\
\text { Other causes-haemolytic } \\
\text { disease, hepatic disease } \\
\text { or the nephrotic } \\
\text { syndrome (unlikely in } \\
\text { athletes) }\end{array}$ \\
\hline
\end{tabular}

${ }^{1}$ Postulated

The factors which may combine to cause haemoglobinuria after exercise have been listed in Table II.

I am grateful to Dr. S. E. Finlay for allowing us to study his patient, and to Professor G. H. Lathe and Professor
Paul Fourman for helpful discussion and for reading th manuscript. The red cell metabolism studies were kindiy done by Dr. Colin Toothill and the ${ }^{51} \mathrm{Cr}$ red cell survivgl studies by Dr. Ivor Surveyor.

\section{REFERENCES}

Allison, A. C., and Rees, W. A. (1957). Brit. med. J., 2, 1137.

Attlee, W. H. W. (1937). Lancet, 1, 1400.

Bodman, J. (1960). Chromatographic and Electrophoretic Techniqu edited by I Smith, vol, 2, P. 91 Heinemann, London

Brin, M., and Yonemoto, R. H. (1958). J. biol. Chem., 230, 307. Buckle, R. M. (1965). Lancet, 1, 1136.

Crosby, W. H. (1965). J. clin. Path., 18, 260.

Dacie, J. V., and Lewis, S. M. (1963). Practical Haematology, 3rd efg Churchill, London.

Davidson, R. J. L. (1964). J. clin. Path., 17, 536.

Ensor, C. W., and Barratt, J. O. W. (1903). Med. -chir. Trans., 86, 165

Gilligan, D. R., Altschule, M. D., and Katersky, E. M. (1943). J. clì Invest., 22, 859.

Gottlieb, A., Wisch, N., and Ross, J. (1963). Blood, 21, 129.

Hunter, F. T., Grove-Rasmussen, M., and Soutter, L. (1950). Amer. clin. Path., 20, 429.

Kast, A. (1884). Dtsch. med. Wschr., 10, 840.

Laurell, C. B., and Nyman, M. (1957). Blood, 12, 493.

Martin, H., and Kilian, P. (1959). Folia haemat. (Frankfurt), 4, 92.

Nagel, R. L., and Ranney, H. M. (1964). Science, 144, 1014.

Pare, C. M. B., and Sandler, M. (1954). Lancet, 1, 702.

Smithies, O. (1955). Biochem. J., 61, 629. 